Chapter 3

\title{
Facilities for Obtaining Soybean Oil in Small Plants
}

\author{
Ednilton Tavares de Andrade, \\ Luciana Pinto Teixeira, Ivênio Moreira da Silva, \\ Roberto Guimarães Pereira, \\ Oscar Edwin Piamba Tulcan and \\ Danielle Oliveira de Andrade
}

Additional information is available at the end of the chapter

http://dx.doi.org/10.5772/52477

\section{Introduction}

In this chapter we will study the processes, procedures and types of equipment used in industrial processing of soybeans for obtaining vegetable oil and its adequatestorage in small plants.

Soybeans, despite its low oil content ( $18 \%$ to $22 \%$ ) is the second most important oilseed crop of the world, after palm oil. In 2010, it represented $27.3 \%$ of vegetable oil total produced worldwide, compared with $33.7 \%$ palm oil (pulp and almond), $15.6 \%$ rapeseed oil and $8.7 \%$ sunflower oil, together are account for $85.3 \%$ of vegetable oil total produced globally [12]. The high protein content ( $37 \%$ to $40 \%$ ) of soybean is the main feedstock in the manufacture of feed for domestic animals. Almost $70 \%$ of meal protein that makes up the animal feed comes from soybean [7].

The demand for vegetable oils will grow, mainly by increased consumption / capita in emerging countries. The average annual consumption of edible oil of a citizen of a developed country is about 50 liters, while the world average is about 20 liters / head / year. Another factor that will contribute to this increase is the use as biofuel (biodiesel and H-Bio), the new lever to consumption of vegetable oil.

The soybean oil currently holds the 2nd position in the world supply of oils and fats, according to Oilworld. In 1990, production of oil stood at around 16.1 million tonnes, followed by palm oil with 10.8 million tons. Other vegetable oils were the significant world production of rapeseed and sunflower, both with approximately 8 million tons, and cotton and peanuts, with 
approximately 4 million tons each. Although interchangeable, each one of these oils has specific characteristics that makes it more or less appropriate depending on its final use [12].

While the supply of vegetable oils is large, each of these oils have specific characteristics that make them more or less suitable for use as a biofuel [12]. The restriction on the use of soy for biodiesel is compared to the low oil content in their grains. The oil yield per hectare of soybean, considering an average oil content of $20 \%$ and within the grain yield per area of 400 to $800 \mathrm{~kg}$ in a crop that produces 2000 to $4000 \mathrm{~kg} /$ ha, respectively [21]. The yield of soybean is around 2.8 to $2.95 \mathrm{t} /$ ha.

According to the USDA (U.S. Department of Agriculture United States) for the 2010/2011 harvest, the estimate of global soybean production was of 256.1 million tons (Table 1), down $1.46 \%$ compared to 259.89 million tons produced in 2009/2010. Likewise, the global consumption of $2010 / 2011$ was estimated at 255.284 .000 tons, an increase of $7.5 \%$ compared to 237.430.000 tons achieved in the previous crop. Still, world ending stocks of the product in 2010/2011 will be at 58.21 million tons, 3.26\% below the world ending stocks of previous crop (2009/2010) of 60.17 million tons.

\begin{tabular}{lrr}
\hline \multicolumn{1}{c}{ Country } & Harvested Area (Million Hectares) & Production (1000 MT) \\
\hline United States & 29.800 & 83.172 \\
\hline Brazil & 25.000 & 68.500 \\
\hline Argentina & 18.600 & 46.500 \\
\hline China & 7.650 & 13.500 \\
\hline India & 10.270 & 11.000 \\
\hline Paraguay & 2.600 & 5.000 \\
\hline Canada & 1.542 & 4.246 \\
\hline Russia & 1.180 & 1.749 \\
\hline Ukraine & 1.100 & 2.200 \\
\hline Uruguay & 1.000 & 1.700 \\
\hline Bolivia & 900 & 1.580 \\
\hline World Total & 103.094 & 245.065 \\
\hline
\end{tabular}

Table 1. Estimates of global soybean production for 2011/2012 harvest [30]

\section{The Product: The Meal and Soybean Oil}

The products of the processes are simplified form the crude oil and meal (cake) semi-defatted, which can be used for the preparation of animal feed. It is planned to be used for human consumption, since such use would imply the need for greater care and sophistication 
in hygiene and microbiological control. There is no waste in the process, which may cause environmental problems.

Compared with the traditional processes, the main disadvantage is the high content of residual oil in the semi-defatted meal (about $8 \%$ ). Soybean oil is very unsaturated and may lead to rancidity bran under these conditions. In a small scale production, it is expected that the soy meal is consumed as it is produced, ie the time of storage would be small. Furthermore, the oil in the meal will replace the oil which is usually added in the preparation of feeds.

The second biggest problem is the allocation of oil produced. Because crude soybean oil, cannot be consumed as food without the refining process - the taste is very bad. Although oil extracted by extraction with low concentrations of phosphatides, which is equivalent to the degummed oil, its storage is not recommended for long periods. Hardly the big oil refiners will buy this product.

In the case of commodities, the market promotes an intense coordination of the system, controlling the prices of commodities. As soybean production-level family does not benefit from economies of scale, the tendency is to seek new ways to add value to the product, incorporating new features into grains. The differentiation of the grains can open prospects for more efficient production, processing or use, making common grains, marketed as mere commodities, specializing in products with high added value and commercial [11, 10].

\section{Production Process}

There are two production processes oils and fats. For materials with high oil contents (over $30 \%)$, it uses the pressing process. For raw materials with lower levels of oil, it uses the solvent extraction. In the extraction by pressing the residual oil content of the raw material is around $10 \%$, while in this extraction solvent content can be reduced to less than $1 \%$.

In industrial processes, typically raw materials rich in oil is pressed up to a residual oil content of about $20 \%$ and the remaining oil is extracted by solvent. Thus, the soybean oil $(20 \%$ oil) is usually extracted only solvent as sunflower oil (45\% oil) is partially removed by pressing and the remaining solvent.

The oil obtained in these processes, known as crude oil, generally undergoes a purification process (refining) before being consumed as food. The only exception is the commercialscale oil (olive oil) olive oil that is consumed without refining (oil "virgin"), although other oils such as sesame, sunflower, peanut oils can be consumed raw. The soybean oil, cotton and canola are consumed only after refined.

The residues of extraction, pie, if the pressing, bran, in the case of solvent extraction, less than $20 \%$ are used for human consumption. They are generally used for the preparation of animal feed.

The oil extraction process can be divided into three phases. The first involves the pre-cleaniness, drying and storage of product to be processed. The second step concerns the prepara- 
tion of the grains for the oil extraction, by facilitating the extraction processes, such as the loss of grain, conditioning or heating, lamination, and expander. Finally, the third stage involves the extraction itself, which may develop by pressing or solvent. Figure 1 details the phases and steps of the extraction process.

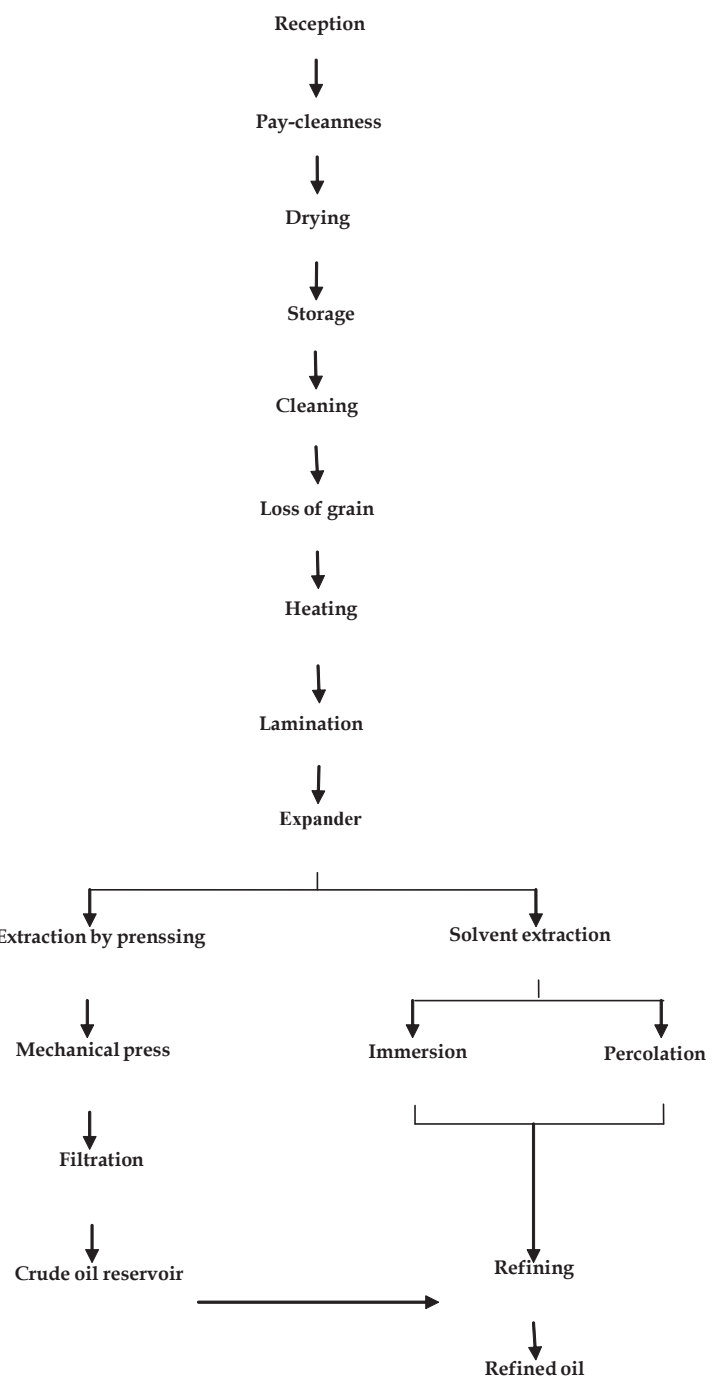

Figure 1. Flowchart for the production of soybean oil 


\subsection{Storage of raw material}

Considering itself it importance of all previous the productive stages the harvest, since the election of the seeds to the cultural treatments, to one adjusted storage, the grains must pass for two important stages: the first one is the daily pay-cleanness, in which all the impurities must be removed, therefore it intervenes directly with the income of the process of oil extraction, useful life of the involved machines, beyond serving as inoculate of plagues and harmful microorganisms. The second stage is the process of drying that has as objective to guarantee the reduction of the moisture content of the product, of form to minimize the deterioration processes during the storage.

The stage of storage is essential for the maintenance of the quality of the raw material to be processed, influencing directly in the final product quality [23]. During the storage of the grains, that must be carried through in silos or specifically projected warehouses, the characteristics of temperature and moisture content of the product they must be monitored. Such characteristics are determinative in the minimization of the losses for deteriorations caused for microorganisms and attack of plagues, beyond being essential to prevent the occurrence of oxidative processes in the interior of the grains.

In what it says respect the quality of the oil during the storage, the variations in the moisture content of the product, as well as of the temperature can provide to enzymatic and oxidative reactions of the present oil in the interior of the grain, providing alterations in the characteristics and disposal of acid the fatty gifts. For the case of the soy grains, the oil if finds deposited in lipid bodies (the Spherosomes) distributed throughout its endosperm. Therefore, the control of such characteristics throughout all the previous stage the extraction of the oil is of basic importance for the guarantee of a quality by-product, as much in artisan scale as in industrial scale. In accordance with [23], low the quality of the crude oil influences in the increase of the losses and expenses with refining, providing a lesser income.

\subsection{Preparation of the raw material}

The extraction of the oil presents as by-products, beyond the involved lipid fraction with the rude oil, also proteins and carbohydrates that constitute the pie or bran, much used in the food industry, as much for animals as for human beings. Therefore, for the guarantee of the quality and not contamination of by-products, the value aggregation, and the integral exploitation of the processed product, must be carried through the preparation of the grain the form to guarantee a maximum separation between the oil and the bran.

In what the oil production says respect proceeding from the soy grain, that presents about $20 \%$ of oil, two methods extraction can be used: the solvent extraction for and the extraction for pressing. Although some authors to characterize the extraction for pressing of the soy as not being economically interesting in reason of its low oil content, indicating the extraction for solvent, in this book will be presented the preparations of the necessary raw material for the two forms of extraction.

The purpose of the stage of preparation of the grain for the extraction of the oil involves to provide the increase of the susceptibility of disruption of lipid organelles, contained in en- 
dosperm, through thermal and mechanical treatments. For this, after the withdrawal of the mass of grains of the storing unit, with moisture content of approximately $10 \%$, in wet base (b.w.), is indicated, again the separation of the impurities that still can be contained in the mass of grains.

After this stage, must be carried through the form grain in addition to lead the unfastening and the separation of the rinds, that are abrasive, and to favor the uniformity of the size of particles to be processed. The grain in addition can be carried through by means of a breaker called equipment of coil that consists of the disposal of two corrugated cylinders, parallel made use that turns with different speeds, while the mass of grains is lead between them. During this process, for the withdrawal of the remaining rind a pneumatic aspiration is carried through, jointly with bolters splitting.

In this process of in addition the grains the milling of the grain is not indicated, since it negative intervenes with the separation between the rind and the remaining structure of the grain, the cotyledon; beyond, for the case of the extraction for solvent, to make it difficult the separation of the solvent and the oil of the bran. Another important determinative characteristic in the success of this stage is the maintenance of the grains with moisture content of, approximately, 10\%, in b.u., of form to prevent the embouchement of the machine for higher the moisture content cases, or the dust production for very low moisture contents.

After the grain in addition, must be carried through the baking of the processed mass of grains. This stage has as objective to provide to a fast increase of the moisture content of the mass of grains, producing a bigger plasticity to the mass, and minimizing the dust production. This process is presented as a facilitator to rupture of the Spherosomes cell walls, in order to facilitate the leakage oil.

In accordance with [18], the increasing of the moisture of the flakes, the cell wall disruption and subsequent increase in the permeability of cell membranes, facilitates the exit of the oil, reducing its viscosity and its surface tension, which allow agglomeration of the oil droplets and its subsequent extraction. The baking can be carried through by warm vertical cookers through chambers with warm vapor, or horizontal rotating drums for a warm tubular beam the vapor.

After this preparation of the raw material, mainly for the case of the extraction with solvent, is indicated the accomplishment of plus others two stages: the lamination and the expansion. These two stages have the objective in the distance to provide the minimization of between solvent and the oil, favoring the extraction process.

The lamination if bases on the flake attainment from pieces of grains, with the objective to minimize the internal resistance in favor of the extraction of the oil. For the confection of flakes, the grains broken and with raised temperature more are lead, in the rolling mill, enter a pair of made use smooth cylinders horizontally that $0,3 \mathrm{~mm}$ jam pieces of the grains of soy in blades of 0,2 , forming flakes [23]. In this process, the flake production with homogeneous thickness directly is related with the efficiency of extraction of the oil and, mainly, with the quality and pureness of the produced bran, since this characteristic influences in the interaction between the oil and the solvent during the extraction. 
The following stage is called of expansion. In this stage, the flakes are, again, humidified with warm water vapor and for attrition throughout screws without end that lead the material until a perforated plate. In reason of the difference of pressure before and after the ticket for this plate, the warm and humidified flake suffers the process from expansion. In accordance with [23], this expansion occurs in reason of the starch presence in the grain.

The ticket of the mass of grains for the expander, or expander - extruder, propitiates greater porosity to the mass and permeability to solvent, favoring the contact between solvent and the expanded cell, guaranteeing a more efficient percolating between the oil the solvent. According [23], the use of the expander implies in the increase of about $40 \%$ in the capacity of extraction for solvent. After the expansion, the material must be cooled until the temperature of extraction of the oil, and depending on the conditions of the processing, the mass must pass for the form drying to guarantee a bigger efficiency in the extraction process.

\subsection{The extraction}

The extraction of the oil for being carried through two different methods: the extraction mechanics through the pressing, or by means of the chemical extraction for solvent. In situations special, of form if to get the maximum efficiency of extraction it can be used the two methods sequentially. To follow, the two forms of oil extraction will be presented proceeding from oil seeds, as it is the case of the soy.

\subsubsection{Extraction for pressing}

The method of extraction for pressing consists of the withdrawal of the oil by means of the application of a external pressure on the mass of grains, through the pressing mechanics. As main involved advantages with the use of the press mechanics for the oil extraction low cost of installation is its, not the use of solvent, and not the necessity of posterior refining of the oil, what it implies in the reduction of the processing cost and, consequently, of the gotten oil, favoring the use of the same one for small producers.

Currently, the press more common mechanics is the continuous press of screw, also call of expeller, that hopper of feeding is composed for one, that leads the material to be pressed by means of a screw without end of step interrupted for steel rings, made use parallel; to the end of the set, they find if a cone tip that regulates the speed of exit of the pie and the chamber pressure on the mass.

The pressing process if develops from the introduction of the mass of grains in hopper that it feeds the screw without end, compressing it against steel rings, providing the elimination of the oil for the orifices. The extraction speed depends directly on the imposed pressure, that initially must understand of 300 the $400 \mathrm{~kg} \mathrm{~cm}^{-2}$, but throughout the process due to the gradual accumulation of mass in the interior of the press, the pressure can be superior the $1,000 \mathrm{~kg} \mathrm{~cm}^{-2}$ [23].

During the process, the mass of grains equally is pressed, preventing the resorption of the oil for other parcels of the mass. After the ticket for the press, the rude oil must be filtered with the purpose to separate the solid residues proceeding from the remaining pie. 


\subsubsection{Extraction for solvent}

The oil extraction for solvent can be used as only method of extraction, or same as complement to the extraction mechanics, in the daily pay-extraction form. This method of extraction if bases on the absorption of the solvent for the lipid cells, where in its interior it has the dissolution of the oil, that, later, for leaching, he is loaded for the exterior of the cell. This process, in adjusted conditions, approximately removes $99 \%$ of the oil contained in the mass of grains [23].

However, for the guarantee of the efficiency of the process, it is essential the adjusted preparation of the grain and the choice of to be used extractor, of form to guarantee the maximum contact of the solvent with the cellular wall. Of this form, how much bigger it is the amount of cells breached throughout the preparation of the mass of grains, faster it is the extraction process, since the solvent will only go to dissolve the free oil, not needing to carry for diffusion the dissolved oil to the external region to the cell.

In accordance with [23], the transport of lipid throughout the cellular membrane occurs in function of the variation of its permeability (initially impermeable to the lipid) in function of the difference of the internal and external osmotic pressures to the cells. The increase of intracellular pressure in virtue of the action of the solvent it provides the expansion of the membrane and, consequently, the dilatation of the pores of the cellular membrane, allowing the ticket of the solvent oil solution and for the extracellular region, which had to the gradient of existing concentration [23, 26].

The extraction process occurs in higher temperatures, seen its influence in the viscosity of the solvent oil mixture and, and in the solubilization of the oil in the solvent. The extraction speeds from beginning to end of the process of solvent extraction progresses differently. Initially, when the oil of better quality is extracted, the process if develops of fast form, due to the biggest gradient of concentration, however, throughout the process this speed diminishes, and the extracted oil to the end presents minor quality, in reason, mainly, of the presence of other cellular composites that provide losses throughout the refining.

From this process, the oil extraction for solvent can be developed of two forms, for immersion, where the mass of grains is kept immersed in the solvent for a definitive period of time, or by percolating, which the mass of grains is made use in layers to guarantee optimum contact of the solvent that it passes freely between the grains and it is renewed when it has saturation. To the end of the extraction, as much the solvent mixed to the oil, as the solvent gift next to the remaining bran can be recouped and be reintroduced in the process. For the grains to solvent extraction with low concentrations of oil is indicated by immersing the system [2].

For the extraction of the oil, frequent the commercial hexane is used as solvent. Proceeding from the refining of the oil, the hexane presents determinative characteristics for its good performance as solvent, as: it is a composition to apolar total being miscible in oil at the same time that it is immiscible in water, presents low latent heat of boiling, and it does not react with the constituent material of the equipment used for the extraction. Although its favorable characteristics physicist-chemistries, this solvent requires special care with the se- 
curity in the industrial plant and with its manuscript, seen its high inflammability, explosion and toxicity [23].

\section{Refining}

The refining if characterizes as the set of operations carried through after the process of extraction for the removal of residues gifts in the crude oil that can affect the color, stability, aroma, and flavor, beyond its physical characteristics. These residues are preceding from drag mechanics, and/or solubilization of other substances in the oil or solvent the occurrences during the extraction process.

The refining takes place in two stages: the first step is the physical removal of substances, while the second involves the refining processes through neutralization, clarification, and deodorization. In accordance with [31], initially the oil passes for a stage of physical separation, where, in a tank, the separation for gravity of insoluble substances is carried through. After this stage, the oil passes for the degumming that consists of the removal of phospholipids, sugars, resins, and breaks up of soluble proteins in water.

In accordance with [23], the presence of phospholipids in the soy oil favors the occurrence of losses, in reason of the formation of depositions with presence of about $35 \%$ of oil in the deep one the tanks of deposition, with aspect similar to a gum. In this in case that, the phospholipids can be presented of two forms: hydratable, being liable of withdrawal with addition of water and centrifugation, and not hydratable that needs the addition of acid citric phosphoric or for becomes it hydratable for its posterior withdrawal.

Still of according to [31], after the degumming process, must be proceeded with the neutralization, that the withdrawal of fatty acid involves, pigments, remaining phospholipids of the degumming, and soluble sulfur composites in water. In the neutralization process it has the caustic soda water addition, with fatty acid the purpose to reduce the text of free, to clot the phosphatides and the gums, to degrade part of the dyes gifts, and to load the insoluble substance for the clotted material. Of this process it has the production of you leave organic sodium or soaps, what it results in the necessity of one another stage, the laundering.

The laundering is a process that results in the withdrawal of the soap produced during the neutralization. It is based on the distilled water addition the temperature of $85-95^{\circ} \mathrm{C}$ (about $10-20 \%$ of the volume of oil) for the elimination of the soda water and the foam of the oil, however case the separation between the oil and the water is difficult indicates it dilution in the aluminum sulfate water. The laundering process can more than proceed a time until the total exemption from soap from the oil. To finish the process laundering, in reason of the water addition, the drying must be proceeded from the oil.

After the drying, the oil is directed to the clarification (bleaching) that objective the pigment elimination, residual products of the oxidation, metals weighed, and soaps, of form to guarantee the improvement of the flavor, odor and oxidative stability of the oil. Bleaching occurs from the adsorption of specific adsorbents substances for the elimination of substances that 
confer coloration, sulfur, soaps and metals to the soy oil. The adsorbents substances can be some types of silicates, diatoms lands, clays acid activated, silica and active coal [23].

In accordance with [14], throughout the refining, the clarification produces an oil with bigger susceptibility to the oxidation, being indicated for the storage the use of absent nitrogen stream bed of oxygen.

After the clarification, the oil follows for its last stage of refining, the deodorization. The deodorization of characterizes for the substance elimination formed during the storage and processing of the grain and other natural substances of the oil that can provide to awkward flavor and odor. For the withdrawal of these substances to use it distillation with chain of vapor to the vacuum, of form to guarantee the protection of the oil to the effect of the atmospheric oxidation, prevention of hydrolysis for the vapor, and the reduction of the necessary amount of vapor for the process.

For some types of oils, as it is the case of the palm oil and peanut, the physical refining is proceeded after the accomplishment from the deodorization. The physical refining consists of the elimination for evaporation of fatty acid the free gifts in the oil, providing bigger income of the fine oil. For the case of the soy oil, the physical refining is not indicated, in reason of its low acidity after to the end of the process and the difficulty in the degumming process.

\section{Quality}

Every product has a number of characteristic attributes. It's called quality, whose existence will define the success or failure in their marketing. This quality is mainly observed by two fundamental aspects: the first relates to the consumer who seeks desirable characteristics, whether from an economic standpoint, nutritional, aesthetic, etc. The second aspect refers to the legality, where the product goes through a series laboratory analysis and is classified into pre-established standards and its final quality is attested.

According [13], quality can be defined as a set of characteristics that will directly impact on the acceptability of the product. In this context, the subjectivity of the sensory analysis of each person are determinants for to preset of the quality, that can involve the appearance, texture, flavor and aroma.

The color, size, shape, integrity and consistency are factors directly involved in the appearance of the product, already the relateds with the physical senses of touch, and mouth are determined on the according to texture; the flavor factors involve the taste, the aroma, and correlate with the olfactory sensitivity. Besides these, you can also to relate the after taste that occurs according to a secondary analysis of the product [13].

Associated with these organoleptics factors for the acceptance of the product are also the nutritional value, the presence of toxic substances and the final price. All these characteristics are to related to the type of raw material and production method. In the case of vegetable oils, with is the case of the soybean oil, these factors are directly related to the conditions of 
storage and processing of the beans, as has been seen above, as well as the characteristics, extraction and treating the produced oil, and form of storage and shipping.

Overall, the changes and loss of quality of the agricultural products are related with the growth and activity of microorganisms, the action of enzymes, chemical reactions, attack by insects and rodents, and physical changes caused by mechanical agents. According [17], the major causes of food deterioration are, respectively, the attack of microorganisms and oxidative processes.

The vegetable oils have fewer characteristics in your reactive molecule, unlike proteins and carbohydrates presents in the grains. The reactivity of the oil is concentrated, mostly, in the hydrolysis that produces free fatty acids according to the moisture content present, lipolytic enzymes and temperature, and the oxidation reaction of lipid compound that is a function of the concentration of oxygen in the medium.

The hydrolysis process provides the breakdown of triglycerides and therefore the increase of free fatty acids, that influences the acidity of the vegetable oil. High levels of acidity in vegetable oils leads to high losses during the refining stage [23]. However, in general, for to monitor the deterioration of the vegetable oils is accomplished due to the oxidative reactions occurred in the triglyceride molecule.

\begin{tabular}{|c|c|c|c|c|c|c|c|c|c|}
\hline \multirow[t]{2}{*}{ Oils } & \multicolumn{8}{|c|}{ Fatty acids composition (Wt.-\%) } & \multirow[b]{2}{*}{ IV } \\
\hline & $12: 00$ & $14: 00$ & $16: 00$ & $18: 00$ & 18:01 & $18: 02$ & 18:03 & $22: 01$ & \\
\hline Canola & 0 & 0 & 4.5 & 1.5 & 58.5 & 25 & 9 & 1.5 & 118 \\
\hline Corn & 0 & 0 & 11 & 2 & 36 & 50 & 1 & & 121 \\
\hline Sunflower & 0 & & 6 & 4.5 & 32 & 57.5 & & & 126 \\
\hline Soybean & 0 & & 8 & 4 & 28 & 53 & 7 & & 130 \\
\hline
\end{tabular}

Table 2. Vegetable oils fatty acid composition

According [24], all vegetable oils consist primarily of triglycerides. The triglycerides have a three-carbon backbone with a long hydrocarbon chain attached to each of the carbons. These chains are attached through an oxygen atom and a carbonyl carbon, which is a carbon atom that is double-bonded to second oxygen. The differences between oils from different sources relate to the length of the fatty acid chains attached to the backbone and the number of carbon-carbon double bonds on the chain. Most fatty acid chains from plant based oils are 18 carbons long with between zero and three double bonds. Fatty acid chains without double bonds are said to be saturated and those with double bonds are unsaturated (Misra and Murthy, 2010).

In general, vegetable oils are made especially for fatty acids with chains between 12 and 24 carbons: Lauric (C12:0), Myristic (C14:0), Palmitic (C16:0); Palmitoleic (C16:1) Stearic (C18:0), Oleic (C18:1), Linoleic (C18:2); Linolenic (C18:3); Arachidic (C20:0); Gadoleic (C20:1); Behenic (C22:0), Erucic (C22:1); Lignoceric (C24:0). The proportions of the fatty acid composition 
can be determined by gas chromatography method. The weight composition of fatty acids found in soybean oil was: $\mathrm{C} 16: 0=11.6 \%, \mathrm{C} 16: 1=0.1 \%, \mathrm{C} 18: 0=32 \%, \mathrm{C} 18: 1=20.4 \%$; $\mathrm{C} 18: 2=57.1 \%$ and $\mathrm{C} 18: 3=5 \%$ [24].

Average values of the chemical composition of vegetable oils and values of iodine index are presented in the Table 2 [15] and physical properties of soybean oil in Table 3. The iodine Index or Number is one characteristic of the oil that measures its index of unsaturation, when evaluating the amount of iodine necessary to saturate the double links of the molecule.

\begin{tabular}{lc}
\hline \multicolumn{1}{c}{ PROPERTY } & SOYBEAN OIL \\
\hline Density $\mathrm{kg} / \mathrm{L}\left(20^{\circ} \mathrm{C}\right)$ & 0.92037 \\
\hline Viscosity $\mathrm{mm}^{2} / \mathrm{s}\left(40^{\circ} \mathrm{C}\right)$ & 30.787 \\
\hline Flash Point ${ }^{\circ} \mathrm{C}$ & 332 \\
\hline Cloud Point $^{\circ} \mathrm{C}$ & -2 \\
\hline Pour Point ${ }^{\circ} \mathrm{C}$ & -14 \\
\hline Copper strip corrosion & $1 \mathrm{~b}$ \\
\hline
\end{tabular}

Table 3. Physical properties of soybean oil [24]

Both the hydrolysis reaction as the oxidation reaction can also be influenced by temperature, light, presence of unsaturated fatty acids, moisture content, and product type. As a result of these reactions is the development of different flavors and odors that compromise the quality and acceptability of the product. For these changes organoleptics give the name of rancidity. Addition, for the production of biodiesel, the presence of free fatty acids in vegetable oils affect the process of separation of soaps, and influence on the reactions of esterification, compromising the efficiency of the process.

Thus, in that it involves, specifically, the oxidation of lipids, the main causative factors are the composition of fats, the presence of oxygen, temperature, and luminosity. The composition of fats influence on the presence of unsaturation in the molecule, as the unsaturation increases the susceptibility of oxygen absorption, that the more present in the environment, more available for the reactions is presented. Both the temperature and luminosity influence, proportionally, in the rates of reactions. For the specific case of light, its presence influences on accelerating the development of rancidity in fats.

According [8] and [27], the quality of the oil can be followed depending on the index of acid determined by the presence of free fatty acids; index of saponification which demonstrates the presence of oils or fats high proportion fatty acids, color; foaming, viscosity, density, and index of peroxide that is determined by the presence of iodine. According to [24], the Table 3 shows the properties of the soybean oil.

It is shown in Table 4 that vegetable oils present corrosion within the pattern established for diesel oil (Standard corrosion $=1$ ) according to ANP. 


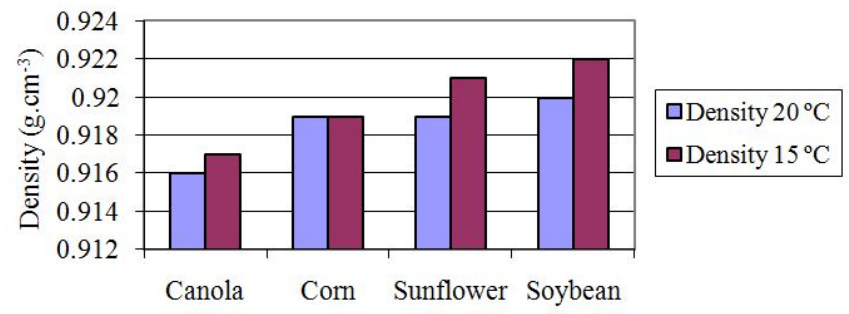

Figure 2. Density in temperatures of 15 and $20^{\circ} \mathrm{C}$

\begin{tabular}{cc}
\hline Vegetable Oil & Corrosivity \\
\hline Canola & $1 \mathrm{a}$ \\
\hline Sunflower & $1 \mathrm{a}$ \\
\hline Corn & $1 \mathrm{a}$ \\
\hline Soybean & $1 \mathrm{~b}$ \\
\hline
\end{tabular}

Table 4. Corrosivity of vegetable oils at temperature of $100^{\circ} \mathrm{C}$

Looking at Table 5, 6 and 7, canola oil has the lowest density of $0.917 \mathrm{~g} . \mathrm{cm}^{-3}$ at a temperature of $15^{\circ} \mathrm{C}$ and 0.916 g.cm ${ }^{-3}$ at a temperature of $20^{\circ} \mathrm{C}$ and soybean oil has the highest density, $0.922 \mathrm{~g} . \mathrm{cm}^{-3}$ at a temperature of $15^{\circ} \mathrm{C}$ and sunflower and corn oil showed a higher density at a temperature of $20^{\circ} \mathrm{C}, 0.919 \mathrm{~g} . \mathrm{cm}^{-3}$. According to the specifications of the ABNT standard, diesel has a density of around $0.865 \mathrm{~g} \cdot \mathrm{cm}^{-3}$ (Figure 2).

In Table 3 the mean values and standard deviation of the viscosity of vegetable oils are shown.

\begin{tabular}{ccc}
\hline Vegetable Oil & Kinematic Viscosity $\left(\mathrm{mm}^{2} \mathbf{s}^{-1}\right)$ & Standard deviation \\
\hline Canola & 35.5278 & 0.0081 \\
\hline Sunflower & 31.7275 & 0.0726 \\
\hline Corn & 33.7713 & 0.0409 \\
\hline Soybean & 31.6107 & 0.0093 \\
\hline
\end{tabular}

Table 5. Kinematic viscosity values of vegetable oils obtained experimentally

The test results of kinematic viscosity of vegetable oils are shown in Figure 3 below: 


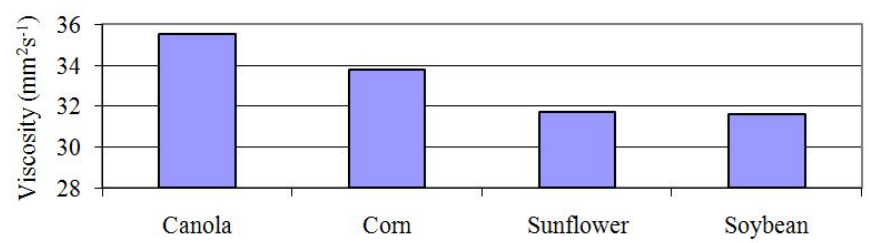

Figure 3. Kinematic viscosity of vegetable oils

Table 6 show the temperatures measured in the tests of cloud.

\begin{tabular}{ccc}
\hline Vegetable Oil & \multicolumn{1}{c}{ Temperatures of Cloud Point } & Temperatures of Flow Point \\
\hline Canola & $-1^{\circ} \mathrm{C}$ & $-20^{\circ} \mathrm{C}$ \\
\hline Sunflower & $1^{\circ} \mathrm{C}$ & $-18^{\circ} \mathrm{C}$ \\
\hline Corn & $3^{\circ} \mathrm{C}$ & $-12.5^{\circ} \mathrm{C}$ \\
\hline Soybean & $-2^{\circ} \mathrm{C}$ & $-18.5^{\circ} \mathrm{C}$ \\
\hline
\end{tabular}

Table 6. Temperatures of cloud points and flow points of vegetable oils

Vegetable oils have a density slightly larger than that of diesel fuel and below water, they are products of easy handling and processing. Their viscosities are far from being similar to diesel fuel, but this allows their use in cases of thermo-chemical conversion without major problems, and are easy to carry through pipelines without large deformation of tension and energy.

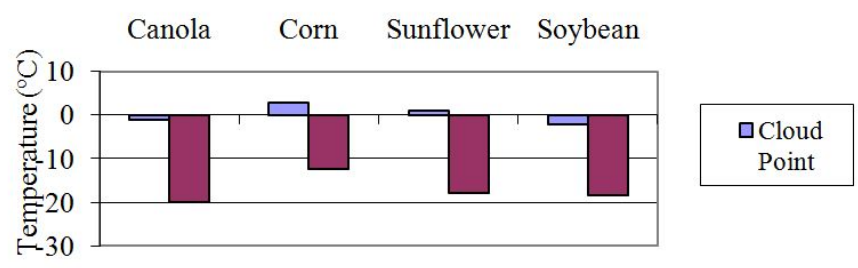

Figure 4. Results obtained experimentally for cloud point and flow point of vegetable oils

\section{Control the Production Management of Soybean Oil}

The acquisition process of vegetable oils occurs through of relatively simple procedures, starting with the attainment of oilseeds, proceeding to mechanical extraction, filtering and marketing of oil. This understanding contributes to the study of the entire production chain. 
Generally the oil extracted is sent to the food industry, or the production of biofuels, and in some cases is used as feedstock in other industrial processes. Soybean oil has its applications in the first two cases cited. [16] agribusiness of the soybean oil has a high processing capacity, with oil production exceeding 50 million liters per year.

\begin{tabular}{|c|c|c|c|c|c|c|c|c|c|}
\hline Vegetable oil & $\begin{array}{c}\text { Density } \\
15^{\circ} \mathrm{C}\end{array}$ & $\begin{array}{l}\text { Standard } \\
\text { deviation }\end{array}$ & $\begin{array}{c}\text { Density } \\
20^{\circ} \mathrm{C}\end{array}$ & $\begin{array}{l}\text { Standard } \\
\text { deviation }\end{array}$ & Corrosion & $\begin{array}{c}\text { Kinematic } \\
\text { Viscosity } \\
\left(\mathrm{mm}^{2} \cdot \mathrm{s}^{-1}\right)\end{array}$ & $\begin{array}{l}\text { Standard } \\
\text { deviation }\end{array}$ & Cloud point & $\begin{array}{l}\text { Flow } \\
\text { point }\end{array}$ \\
\hline Canola & 0.917 & 0.0005 & 0.916 & 0.0005 & $1 a$ & 35.5278 & 0.0081 & $-1^{\circ} \mathrm{C}$ & $-20^{\circ} \mathrm{C}$ \\
\hline Sunflower & 0.921 & 0.0010 & 0.919 & 0.0005 & $1 a$ & 31.7275 & 0.0726 & $1^{\circ} \mathrm{C}$ & $-18^{\circ} \mathrm{C}$ \\
\hline Corn & 0.919 & 0.0005 & 0.919 & 0.0005 & $1 a$ & 33.7713 & 0.0409 & $3^{\circ} \mathrm{C}$ & $-12.5^{\circ} \mathrm{C}$ \\
\hline Soybean & 0.922 & 0.0000 & 0.920 & 0.0006 & $1 \mathrm{~b}$ & 31.6107 & 0.0093 & $-2{ }^{\circ} \mathrm{C}$ & $-18.5^{\circ} \mathrm{C}$ \\
\hline
\end{tabular}

Table 7. Physical characterization of vegetable oils $[29,1]$

It is known specific attributes which must be met after defining the destination of oil extracted, not all characteristics of a product can be easily evaluated. In the case of agri-food products there is the existence of personal or subjective parameters that hinder your judgment. Thus, the oil-producing units paying attention to product quality, this will help to stay in the market and seeing new opportunities.

[3] reported that the quality of a product is resulting from the joining of items:

a. Quality of product design: that is the result of the activities that translate the knowledge of market needs and opportunities in information technology for the production.

b. Quality of design process: is results from the efficient translation of the design specifications of the product in process at various levels, such as process flow diagram, layout, design tools and equipment, project work etc..

c. Quality of conformation: is the result of the efficiency level of actual production.

d. Quality of services associated with the product: it is the result of the quality level of the stages of distribution and marketing, beyond quality of after-sales services.

[16] reported that the limit of the concept of quality has advanced in segments related to the management of the productive sector. It is clear that the companies' survival now depends on the quality of products or services it offered. Several agents have sought to monitor quality through product recalls, allowing verification of consignments dispatched by identifying the weaknesses of the production complex, such as inefficiency in logistics and handling conditions and storage of the product.

The production of vegetable oil in small units can be designed more efficiently by understanding the concept of agro-industrial chain, because according to [20] in recent years the so-called industrialization of agriculture has led to increasing dependence on agriculture to industry. Thus small farmers can participate in a competitive market where strategic alli- 
ances allow to produce and market their products. Given this perception, competitiveness is to migrate the level of individual firms to competition between agribusiness chains. Thus, because it is an integrated system there is a need to coordinate the supply chain, and the search for quality is now undertaking the various agents.

According [3] the coordination of quality is a set of activities planned and controlled by a coordinator agent, in order to improve quality management in the chain and ensure product quality through a process of transaction information, helping to improve the matching of customers and to reduce costs and losses at all stages of the chain.

This concept of quality coordination, "to plan", "controlling" and "improve" the quality management, "the process of information transaction" and "coordinating agent" are:

- Planning: Planning activities in order to create a process capable of producing products that meet consumers;

- Control: Control processes and activities with the objective of evaluating the performance of real quality and act if there is a diversion;

- Improve: set of activities that aims to improve the quality of processes and products;

- Transition process of information: the acquisition, management and distribution of information throughout the production chain;

- Coordinating agent: a key to the coordination of quality aims to make information related to product quality and quality management are identified, communicated and controlled throughout the chain.

The coordinator agent can be a company, a group of companies, an association of representatives of the segments of the agribusiness chain or a third party contracted to perform the tasks for the agent coordinated.

The coordination process quality in agro-industrial chain of soybean oil, produced in small units, can be strengthened by adopting measures to encourage the involvement of its agents. Usually the resources of small producers to cover production are limited, requiring therefore of a reliable outlook for the sale of its production. At this point, there is the need of productive sector strategies are aligned with unusual strategies for the development of the productive chain.

The literature dedicated to the study of agribusiness systems suggests practices to be implemented from the producer to the customer. Measures such as discounted prices, flexibility in time and remuneration for services, contribute to the strengthening of alliances among its members.

The strategies that comprise the agribusiness chain agents, shall consider agribusiness products are subject to special features such as seasonality of production, the need for special conditions for transport and storage and other care as they are perishable. The following paragraphs deal with aspects related to the quality of agro-industrial products, particularly vegetable oils. 


\subsection{Methodologies applied to quality management}

Methodologies will be presented that can be applied to quality management in the production of vegetable oils in small units.

\subsubsection{Application of ISO 9000}

The International Organization for Standadization is responsible for standardization in global character, is the ISO 9000 group linked the quality management systems, which was created searching to standardize the rules for products and industries.

In addition to ISO 9000, regarding the standards focused on vocabulary and fundamentals, there is the importance of ISO 9001 that dealing with Quality Management Systems and Guidelines for SGQs auditing.

A process model of ISO 9001 may be seen as an implementation of the PDCA cycle, according [19], in which:

- PLan: It means setting objectives and processes necessary to deliver products or services in accordance with the requirements and policies of the organization;

- Do: It means the implementation of procedures;

- Check: It means to monitor and measure processes and products by comparing them to the policies, objectives and product requirements and report the results;

- Action: It means to take actions to continually improve process performance.

The most common steps for the implementation of ISO 9001 are:

- Conviction of top management

- Choice of coordinating implementation

- Assessment of current situation

- Preparation of schedule

- Training leveling

- Establishment of working groups

- Specific training

- Process Mapping

- Development / deployment documentation

- Training of internal auditors

- Performing internal audits

- Corrective Actions

- Training end 
- Pre-certification audit, and

- Setting and maintaining the quality management system ISO 9001

\subsection{Hazard Analysis and Critical Control Points (HACCP)}

According [4] the HACCP is based in the analysis method of the mode and effects and fault causes or failure, mode and effect analysis (FMEA), developed by Kaoru Ishikawa in the Japanese industry. The HACCP allows to identify and assess hazards associated with different stages of the food chain, and define the necessary means for its control. The HACCP should be considered as a quality system, a rational practice, organized and systematic, indicated to provide the necessary confidence that a agri-food product will meet the health and safety requirements expected by the consumer.

Studies based on the concept of prevention, developed by [5], concluded that the HACCP represents an advance in food safety, when the adoption of preventive measures promoted the effective design of food safety and the processes in which, a priori, was analyzed quality (microbiological, physico-chemical and sensory) of the products already processed.

\subsection{Traceability}

At first glance, it is believed to be unnecessary to use tools that require high technological standard in small units of oil extraction. However, products offered in different ways may present a promising alternative for small farmers. Traceability aims to identify the origin of the product from the farm to the consumer. This principle is indifferent to processes in which the product has undergone. Thus, it is expected to reach the final with a quality product, and with a known source.

To [9] an efficient screening process should consist of the following elements:

Standards and / or the quality that aim to protect / secure;

Procedures allowed, prohibited, tolerated and required;

Grace periods or transition established as provided in the rules;

Requirement that producers are provided with proof of purchase, sales, everything that allows inspectors to check compliance of standards by the operator (owner of the process);

Periodic visits to the default setting;

Visits "surprise" the establishment.

According to [19] in soybean production, traceability is an essential tool for identification and separation of genetically modified organisms that are restricted in certain countries or markets. Thus, traceability systems are necessary for the management and development of the agribusiness chain, ensuring quality food offered. 


\subsection{Good Manufacturing Practices}

Such standards can be applied in the production of oil intended for human consumption. Procedures are designed to get quality products. The Good Manufacturing Practices (GMP), according to Tomich et al. (2005), are a set of standards used in products, processes, services and buildings, for the promotion and certification of quality and food safety.

According to [6] requires that each establishment has its Manual of Good Manufacturing Practices, which details the conditions of hygiene and sanitary food handling procedures, cleaning equipment, utensils, facilities and buildings of establishments, in addition to establishment of minimum health requirements of buildings, facilities, equipment and tools, control of water supply, health and hygiene of food handlers, the integrated control of pests and vectors, and control and quality assurance of final products.

The following legislation provides for the establishment of Good Manufacturing Practices (GMP), in Brazil, whereas other related items: Standards of Identity and Quality, sanitary inspection, Standard Operating Procedures and Checklist of GMP.

- Ordinance no. MS 1.428/1993

- Ordinance no. 368/1997 of the MAP

- Ordinance no. 326/1997 of the MS / SVS

- Resolution RDC / ANVISA no. 275/2002

\subsection{Cleaner Production: CP}

The methodology of CP is the application of an economic strategy, environmental and technical, integrated processes and products in order to increase the efficiency of use of raw materials, water and energy, not the generation, waste minimization and recycling with environmental and economic benefits to the productive processes.

To have success in the development of cleaner production, are required to exercise responsible environmental management and technology assessment, the initial effort is fundamental in changing attitudes, including a subjective evaluation of the entire process.

All factors imply aggregate values and services, with the primary concern of consuming less material and generate less pollution.

[25] studied the management of agro-industrial residues. As a result it was proposed a roadmap for Environmental Management System (EMS). Operational actions were suggested as: Mass Balance identifying and quantifying infrastructure resources; Anticipation and monitoring the adoption of measures to prevent accidents or damage to the ecological nature of the life cycle analysis of products, Cleaner Production (CP) and Reverse Logistics, which is to collect, package, transport and dispose of waste that were generated in the activities of obtaining Raw Material and managerial actions suggesting adoption of sustainable strategies and policies, Environmental Management System as a mechanism to monitor the administrative and managerial performance the organization, Environmental Audit and Environmental Education. 


\section{From Control to Management}

Currently, the concern with quality extends beyond the aspects mentioned above, no longer a mere bureaucratic requirement of regulatory agencies and inspection, but a fundamental strategy and essential to ensure competitiveness. The quality is replaced by a much broader approach, involving all levels of the organization and process.

\section{Quality attributes}

The main attributes that describe the desirable characteristics in grain for the quality of the bran are high in protein concentration, profile and level of amino acids, especially lysine, and high energy. To control the meal must consider factors such as moisture content, oil content, protein content, the urea activity and the rate of protein digestibility. And in the case of crude oil, emphasizes the determination of fatty acids and their state of rancidity.

These attributes directly influence the quality and safety of the product and the forms of controls are given in the text. It should be laid down the acceptable quality level (EQS) according to the intended use of the product. Obviously, the level of residual bran oil obtained by pressing has maximum and minimum other than the one extracted by solvent. The determination of the EQS should consider the characteristics of the process to optimize your control.

This item will be established quality standards obtained for soybean oil for immediate and latent analysis.

\section{Process Control}

As animal feed, the control of raw materials and products may be carried out with simpler and less frequently. The analyzes have suggested the purpose of controlling the quality of raw materials, products and the process yield. The quality and characteristics of the raw material has great influence on product quality and yield. Soybeans should be free of mold, broken grains, greens and other defects.

During the extrusion process, there is an internal friction of grain against the internal elements of the extruder rising to temperature and pressure with the complete inactivation of the activities: ureatics, antitrypsin and hemoglutinant (anti-nutritional factors). Exposure of the grain at high temperature and pressure for an extremely short time (20-40 seconds) favors the obtaining a quality product without compromising the nutritional quality of soybean. Therefore, factors such as temperature and pressure during the process should be monitored and recorded continuously. In annex presents tables to assist in process control. Below we suggest some analysis should be performed periodically. 


\section{Installations and Equipments}

The following relate to the main points that should be taken into consideration when choosing a site to be deployed to agribusiness:

- the potential for obtaining the raw material in the region should be higher than the projected demand of the plant and enable future expansion in production;

- water supply reliable and good quality (drinking water);

- providing sufficient electrical power without interruption;

- availability of skilled labor, including technical personnel;

- no contaminants of any kind on the outskirts of agribusiness;

- road infrastructure in working condition and easily accessible;

- availability of sufficient area to implement the agricultural industry and its future expansion.

All new property before it began, it must seek approval of their facilities by the regional body of the Labor Ministry or agency responsible, and this after doing a preview, issue a certificate of approval for facilities. This procedure is adopted in order to ensure that the new establishment activities free of accident hazards and / or occupational diseases, which is why the establishment does not meet regulations will be subject to the impediment of its operation until the standard is met.

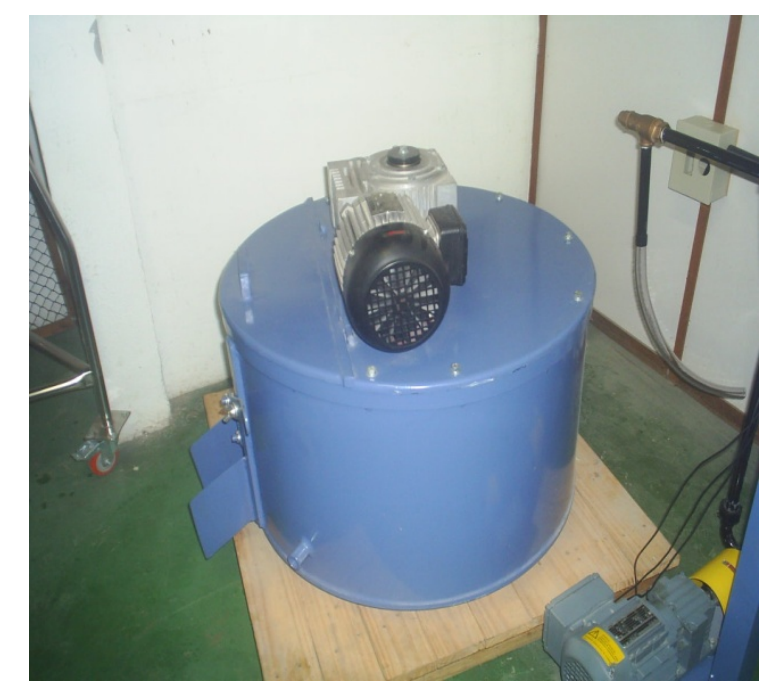

Figure 5. Seed cooker 


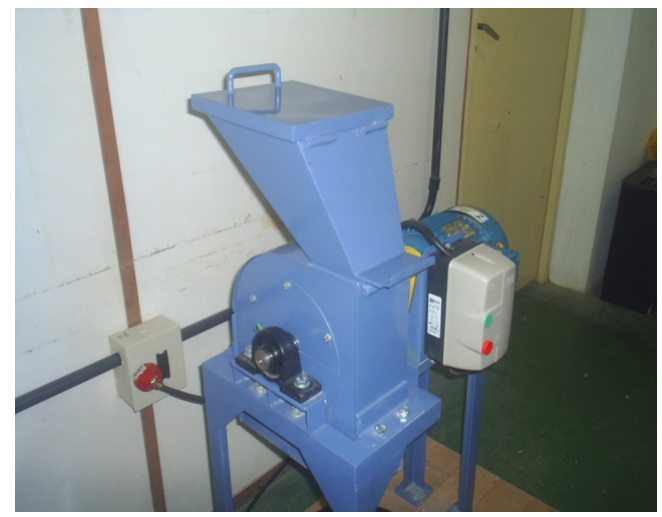

Figure 6. Crusher seeds

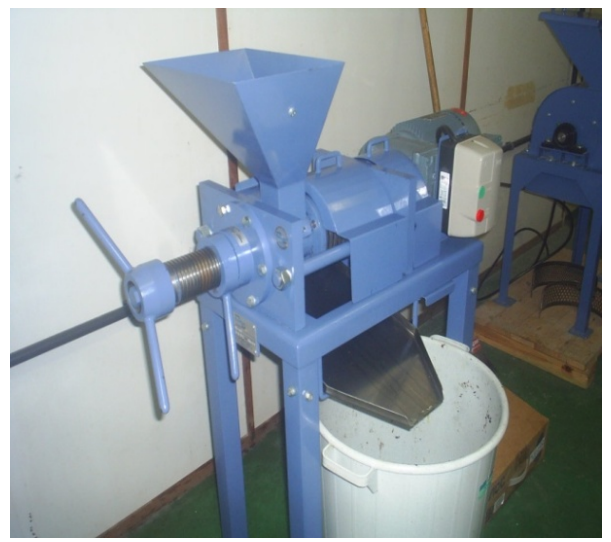

Figure 7. Press small

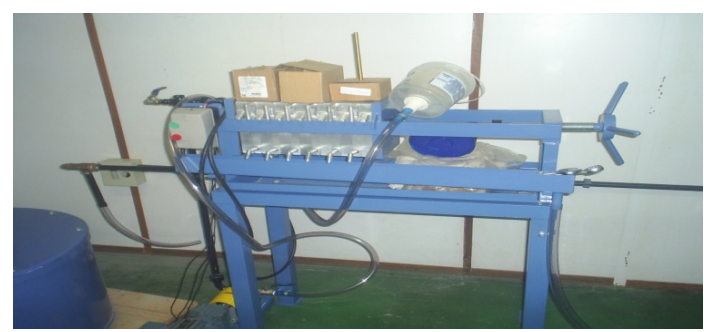

Figure 8. Filter with collect the oil bucket 


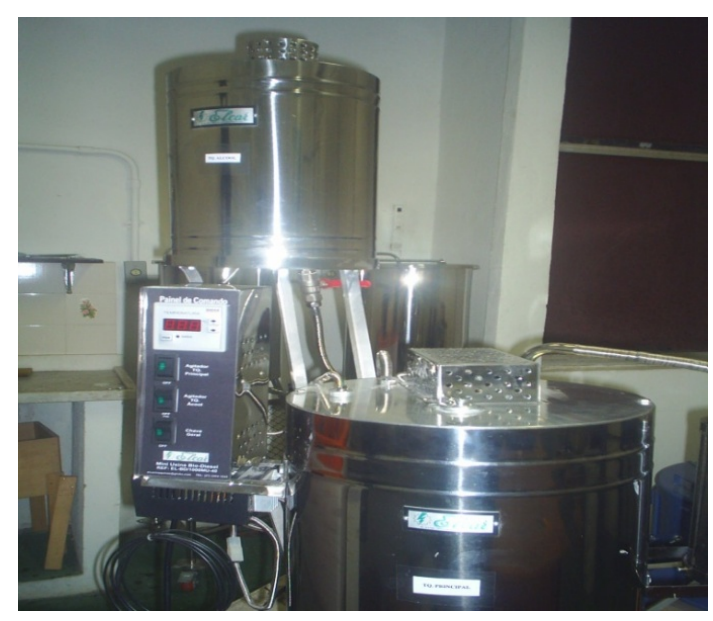

Figure 9. Small plant for the production of biodiesel

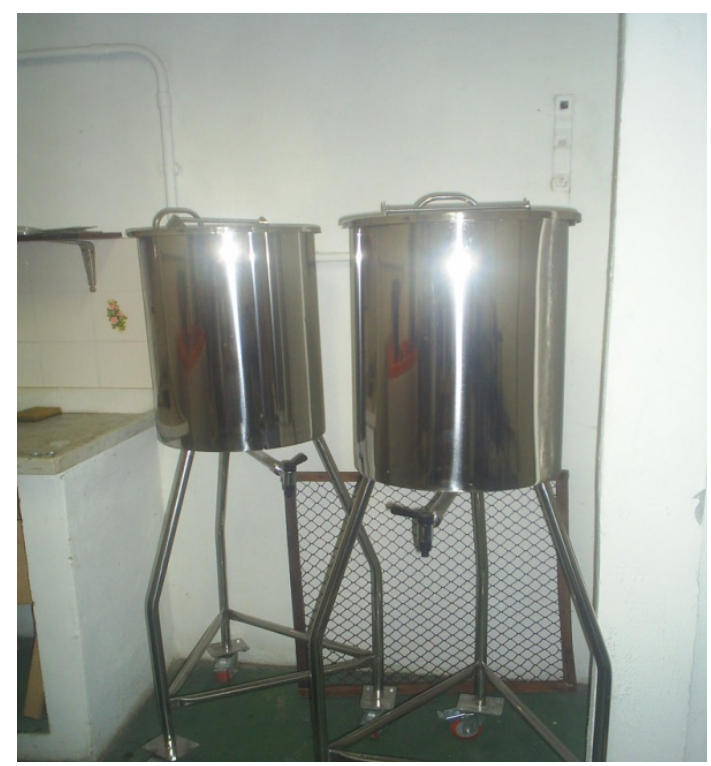

Figure 10. Settling tank to the glycerin

A unit of oil extraction on the farm can be mounted in a simplified form with the elements described below. Figure 5 shows a seed cooker being installed, its use may be waived in work with seeds whose oil extraction is done cold, as in the case of sunflower seeds. The crusher shown in Figure 6 can be used to prepare larger seed. Equipment such as the press 
shown in Figure 7 can perform pressing in an average yield of $40 \mathrm{~kg}$ per hour and is suitable for small applications. The filtration must be done efficiently preventing the oil is lost, thus a device for filtering, with collect bucket oil is of great importance in the process (Figure 8). A small plant, for production of oil and biodiesel, you can compose the oil processing unit (Figure 9). Glycerin resulting product from the transesterification of vegetable oils may be separated by centrifugation or decantation. In the second case, the composition of glycerin biodiesel more tanks can be conducted as shown in Figure 10, which should preferably have conical structure inside facilitating the decanting of the glycerine.

\section{Conclusion}

In conclusion we have with the expansion of soy agribusiness, there is a need to add value to the product. And in case of small farmers or family farmers in the production of oil will allow your own farm profit by adding value, besides the possibility of using this product on the farm.

The values of cloud points, close to zero degrees Celsius, and flow, near minus fifteen degrees, makes manipulation of these oils possible in tropical climates, where temperatures barely reach those levels, do not show stoppage problems, flow and clogging the lines of the process involved with the use of oil.

Tests for corrosion highlights low levels of attack in copper sheets, and oil is a product that does not generate large losses of material in the areas of the process which they have contact with, on the other hand the formation of clogging points and false surfaces as a result of polymerization of oil when working at higher temperatures can be more dangerous.

The physical and chemical characteristics evaluated in this work present a great relation with the composition of the tested oils, where there is a relation between the density, viscosity and corrosion index with the iodine index of the fluid. On the other hand, the cloud and flow points are related with the presence of saturated and unsaturated fatty acids. In respect to the saturation of the oil, it can be favorable in problems such as corrosion, of low temperatures or in the case where lower viscosity values are needed.

\section{Author details}

Ednilton Tavares de Andrade ${ }^{1}$, Luciana Pinto Teixeira ${ }^{3}$, Ivênio Moreira da Silva ${ }^{3}$, Roberto Guimarães Pereira² ${ }^{2}$ Oscar Edwin Piamba Tulcan ${ }^{4}$ and Danielle Oliveira de Andrade ${ }^{3}$

1 Federal Fluminense University/TER/PGEB/PGMEC, Brazil

2 Federal Fluminense University/TEM/PGMEC/PGEB/MSG, Brazil 
3 Federal Fluminense University/TER/PGMEC, Brazil

4 National University of Colombia, Bogota, Colombia

\section{References}

[1] Andrade, D. O., Tulcan, O. E. P., Andrade, E. T., \& Pereira, R. G. (2008). Determination of the physical characterization of vegetable oil. International Conference of Agricultural Engineering, 4.

[2] Bockisch, M. (1993). Fats and oils handbook. Champaign, AOCS, 345-718.

[3] Borrás, Miguel. Ângelo, \& Toledo, José. Carlos. (2006). A Coordenação de Cadeias Agroindustriais: Garantindo a Qualidade e Competitividade no Agronegócio. Zuin, Luiz Fernando Soares; Queiroz, Timóteo Ramos. Agronegócios: Gestão e Inovação. São Paulo: Saraiva, 464, cap. 2.

[4] Borrás, Miguel. Ângelo, \& Toledo, José. Carlos. (2006). Qualidade dos Produtos Agroalimentares: A Importância da Gestão da Qualidade no Agronegócio. Zuin, Luiz Fernando Soares; Queiroz, Timóteo Ramos. Agronegócios: Gestão e Inovação. São Paulo: Saraiva, 464, cap. 7 .

[5] Brum, Jaime. Victor Ferreira. (2004). Análise de Perigos e Pontos Críticos de Controle em Indústria de Laticínios de Curitiba- PR.

[6] Carrazza, Luis. Roberto, Maciel, Luis. Gustavo, Borges, Moacir. Chaves, Cordeiro, Augusto. César Rodrigues., \& Ávila, João. Carlos Cruz. (2011). Caderno de Normas Fiscais, Sanitárias e Ambientais Regularização de Agroindústrias Comunitárias de Produtos de Uso Sustentável da Biodiversidade. SPN-Instituto Sociedade, População e Natureza(ISPN).Brasília- DF, 43.

[7] Dall', Agnol. A., Lazarotto, J. J., \& Hirakuri, M. H. (2010). Desenvolvimento, Mercado e Rentabilidade da Soja Brasileira. Circular Técnico 74. Embrapa Soja, April, 18.

[8] Dobarganes, M. C. (2000). Frying fats: quality control. In: IUPAC workshop on fats, oils and oilseed analysis. Rio de Janeiro. EMBRAPA. Book of conferences, 29-45.

[9] Dulley, Richard. Domingues, \& Toledo, Alessandra. A. Gayoso Franco. de. (2003). Rastreabilidade dos Produtos Agrícolas. Informações econômicas, SP, 33(3), mar.

[10] Embrapa Soja. (2012b). Uso industrial. http://www.cnpso.embrapa.br/index.php? op_page=27\&cod_pai=31, Accessed: 26 March.

[11] Embrapa Soja. (2012a). Uso. http://www.cnpso.embrapa.br/index.php? op_page=25\&cod_pai=29, Accessed: 26 March.

[12] FAO (Food and Agricultural Organization of the United Nations). (2012). http:// faostat.fao.org/site/339/default.aspx, Accessed: 26 March. 
[13] Gava, A. J., Silva, C. A. B., \& Frias, J. B. G. (2008). Tecnologia de alimentos: princípios e aplicações. São Paulo: Nobel.

[14] Hui, Y. H. (1996). Baley's industrial oil and fats products. 5. Ed. Nova York, Wiley, 4.

[15] Knothe, G., Dunn, R., \& Bagby, M. O. (2003). Biodiesel: The Use of Vegetable Oils and Their Derivatives as Alternative Diesel Fuels. Fuels and Chemicals from Biomass. Washington, D.C.: American Chemical Society.

[16] Lima, Suzana. Maria Valle., \& Castro, Antonio. Maria Gomes. de. (2010). A Agroindústria de Óleo Vegetal para a Produção de Biodiesel. Castro, Antonio Maria Gomes de; LIMA, Suzana Maria Valle; SILVA, João Flávio Veloso. Complexo Agroindutrial de Biodiesel no Brasil: Competitividade das Cadeias Produtivas de Matérias-Primas. Brasília, DF: Embrapa Agroenergia, cap. 6.

[17] Lindley, M. G. (1998). The impact of food processing on antioxidants in vegetable oil, fruits and vegetables. Trend in Food Science and Technology, 9.

[18] Mandarino, José. Marcos Gontijo., \& Roessing, Antônio. Carlos. (2001). Tecnologia para produção do óleo de soja: descrição das etapas, equipamentos, produtos e subprodutos. Londrina: Embrapa Soja, 40.

[19] Martins, Roberto. Antônio. (2009). Gestão da Qualidade Agroindustrial. BATALHA, Mário Otávio. Gestão Agroindustrial. GEPAI. $3^{\underline{a}}$ Ed. São Paulo: Atlas, cap. 8.

[20] Mendes, Judas. Tadeu Grassi., \& Padilha, Junior. João Batista. (2007). Agronegócio: Uma abordagem Econômica. São Paulo: Pearson Prentice Hall.

[21] Moraes, R. M. A. (2007). Potencial da soja na produção de biodiesel. http://www.cisoja.com.br/index.php?p=artigo\&idA=1, Accessed: 26 March. 2012.

[22] Moraes, R. M. A. (2007). Potencial da soja na produção de biodiesel.. http:// www.cisoja.com.br/index.php?p=artigo\&idA=1, Accessed: 26 March 2012.

[23] Oetterer, M., Regitano-D’Arce, M. A. B., \& Spoto, M. H. F. (2006). Fundamentos de Ciência e Tecnologia de Alimentos. Barueri, SP: Manole, 612.

[24] Pereira, R. G. ., Tulcan, O. P. ., Lameira, V. J. ., Espirito, Santo., Filho, D. M. ., \& Andrade, E. T. (2011). Use of Soybean Oil in Energy Generation. Dora Krezhova. (Org.). Recent Trends for Enhancing the Diversity and Quality of Soybean Products. Recent Trends for Enhancing the Diversity and Quality of Soybean Products. Rijeka: InTech, 01, 301-320.

[25] Schenini, Pedro. Carlos. (2011). Gerenciamento de Resíduos da Agroindustria. II Simpósio Internacional sobre Gerenciamento de Resíduos Agropecuários e Agroindustriais- II SIGERA.15 a 17 de março de- Foz do Iguaçu, PR, Volume I- Palestras.

[26] Schneider, F. H. (1980). Zur extraktiven lipid-freisetzung aus pflanzlichen zellen. Fette Seifen Antstrichmittel, Hamburgo, 82(1), 16-23. 
[27] Shahidi, F., \& Wanasundra, U. N. (1998). Methods for measuring oxidative rancidity in fats and oils. Akoh, C E Min, D. O. Foods lipids-chemistry, nutricion and biotechnology. Nova York, Marcel Dekker.

[28] Shahidi, F., \& Wanasundara, U. N. (1998). Omega-3 fatty acid concentrates: Nutritional aspects and production technologies. Food Sci. Technol, 9, 230-240.

[29] Tulcan, O. E. P., Andrade, D. O., Andrade, E. T., \& Pereira, R. G. (2008). Analisys of physical characteristics of vegetable oil. International Conference of Agricultural Engineering, 4 .

[30] USDA- United States Department of Agriculture. (2012). http://www.fas.usda.gov/ psdonline/psdQuery.aspx, Accessed: 26 March.

[31] Young, V. (1980). Processing of oils and fats. Hamilton, R. J. E Bhati, A. (eds). Fats and oils: chemistry and technology. Londres, Appl. Sci. Publ, 135-165. 
